\title{
The Politics of Representation and Audience Reception: Alternative Visions of Africa
}

\author{
FLORENCE AYISI \\ University of Wales, Newport \\ florence.ayisi@newport.ac.uk \\ CATALIN BRYLLA \\ University of Wales, Newport \\ catalin.brylla@newport.ac.uk
}

\begin{abstract}
Western media has consistently misrepresented or underrepresented African people and cultures. This article focuses on Florence Ayisi's documentary film practice, which engages with alternative realities and images that portray the lived experiences of African people and how these are manifested in audio-visual representations, including narrative structure and point of view. Her multiple positions as African woman, film lecturer, and filmmaker mean that these documentaries provide a space to challenge the myriad of simplistic representations of African life and societies. The ideas explored in this article will be illustrated through a cross-disciplinary analysis of Zanzibar Soccer Queens (2007, 87 mins.) and Art of This Place: Women Artists in Cameroon (2011, 40 mins.). The academic discourse of this article is situated within several academic disciplines: audience reception studies, cognitive film theory, phenomenology, representation, and African film practice, where the experience of filmmaking is politicized and emerges from postcolonial struggles to redefine and counter cultural misrepresentations.
\end{abstract}

\section{INTRODUCTION}

7 he popular and dominant media output in Western societies has consistently constructed cinematic images of African life and society that are reductive and even offensive. Such visualizations in different media forms have been 
influenced, to a large extent, by histories of slavery and colonialism and neocolonial relationships with the West. In particular, the images and ideas in the works of early European explorers established ideological visions that triggered the circulation of a highly stereotyped and oppressive portrayal of Africa. Film critic and theorist Richard Dyer has argued that " .. . how anything is represented is the means by which we think and feel about that thing, by which we apprehend it" (The Matter of Images xiii). Consequently, these early cultural representations have implications in terms of the kinds of memory and consciousness engendered.

Film and cultural theorists have explored and discussed the various racist ideologies and negative cultural representations of African people in different media by Western anthropologists, ethnographers, and filmmakers. For instance, Nigerian novelist and poet Chinua Achebe examines the way in which Africa is portrayed in Joseph Conrad's Heart of Darkness as "'the other world,' the antithesis of Europe and therefore of civilization, a place where man's vaunted intelligence and refinement are finally mocked by triumphant bestiality" (783). Nevertheless, this negative portrayal is rooted in a deeper ideology than mere imperial dominance. As African novelist and playwright Ngũgĩ wa Thiong'o notes, "the continent provided the terrain ... and its people-particularly the fact of their blackness - provided Europe with a contrasting view of its self-image as the civilized" (239-40). This attempt at cultural self-affirmation is particularly addressed in postcolonial discourses. For example, according to Erik Barnouw, "the exploreras-documentarist tradition received some of its most tawdry contributions in the work of Mr. and Mrs. Martin Johnson . .." (50). He notes that a central element of their films was "self-glorification" and that their attitude toward the people was "unabashed condescension." The commentary for their film Congorilla (1932), for example, includes phrases such as "funny little savages" and "happiest little savages on earth" (50-51). This image of Africans as inferior beings meant a complete absence of any respectable and worthwhile cultural representations. Such attitudes and images had set the agenda for future cultural misrepresentations by rendering the dynamic cultures and traditional values that defined Africans as part of the human race invisible. Olivier Barlet observes that these negative images of black people still persist today (5-6).

The iconic images of war, famine, poverty, disease, misery, and exotic landscapes continue to dominate Western media outputs. Sylvia Wynter has also noted that Africa is still projected as the "extreme form of the 'native Other' to Man" and as the "bottom-most world" (35). These generalizations of what Africa is have significance for the question of (in)visibility as it relates to the representation of African cultures. Whether this is an atavistic development, the result of a collective Western subconsciousness, or a deliberate attempt at intellectual and economical hegemony, this article will engage in an a posteriori discourse by examining how Florence Ayisi's documentary film oeuvre transgresses predominant stereotypical representations of African subjects, in particular women.

\section{CONTEXT OF AYISI'S WORK}

Ayisi's work is situated within various contexts: audience reception studies, poststructural film theory, transnational cinema, and African film practice, where the experience of filmmaking emerged from anti-colonial struggles with a political 
impetus to redefine African histories and identities. African film practice, according to Mbye Cham, has undergone "a process of painful growth and development in a post-colonial context of general socioeconomic decay . . ." (1). Despite the challenges, there has been a consistent effort by African film and video makers on the continent and in the diaspora to produce cinematic images that challenge the negative Eurocentric stereotypes. Films by black African filmmakers, in particular, have produced images that construct a different Africa by refocusing the cinematic lens to redefine histories and identities. ${ }^{1}$

However, Ayisi's films also contribute to African feminist film discourse. Scholars and film critics such as Manthia Diawara, Frank Nwachukwu Ukadike, and Sheila Petty have variously discussed and analyzed the positive portrayal of the African woman in film by African directors. Ukadike notes that these films are "attempting to rehumanize portrayals of women and to reassert their identities." (194). In his analysis of Med Hondo's Sarraounia (1986), Diawara describes the main character, Sarraounia, as "an African woman taking the hero position of Western films and becoming larger than life." (154). Petty remarks on how the work of Safi Faye challenges the "construction of the female subject 'as body" by offering a more "positive direction for women's representation and identification" in films such as Peasant Letter (1975) and Fad Jal, from 1979 (188). These films not only give a voice to women, but they also present dignified images that offer alternative perspectives that challenge how African women are usually portrayed.

Furthermore, Ayisi's films, and African cinema in general, could also be described as being within the broad framework of "Third Cinema," a cinema in opposition to mainstream film institutions with an agenda to "decolonize culture." According to Argentinean proponents Fernando Solanas and Octavio Getino, Third Cinema is the "most gigantic cultural, scientific, and artistic manifestation of our times, the great possibility of constructing a liberated personality with each people as the starting point-in a word - the decolonization of culture" (2-3). However, the difference between Ayisi's documentaries and Third Cinema is of a more ontological nature; the films she makes are part of a counter-discourse, rather than a Marxist-revolutionary movement that aims to fight institutional and intellectual hegemonic structures. They constitute an alternative mode of representation, aiming to expose the hegemonic model by using a counter-hegemonic approach.

This article understands counter-hegemony not as Theodore H. Cohn coined it, "a challenge to the dominant bourgeois-led view" (131), but rather as "a creation of an alternative hegemony on the terrain of civil society in preparation for political change" (Pratt 331-36). In other words, Ayisi's work does not represent an alternative to the mainstream, but an alternative within it. Jacob Groshek and Ying Han warn scholars to reconsider the dogmatic division between mainstream media as hegemonic and alternative media as democratic (1523). Through empirical analyses, they demonstrate that alternative texts are often more fragmented and exclusionary than mainstream ones. In this regard, Ayisi's films do not intend to oppose or negate mainstream representations about Africa (as would have been in the revolutionary spirit of Third Cinema), but to pluralize the mainstream sector itself. For this reason, this article will only focus on her output, instead of offering a comparative analysis with other films. 
There are two main ways in which Ayisi's agenda of pluralism is revealed: her films only use conventional (as opposed to experimental or alternative) film language, in an effort to reach a wide audience and to target mainstream exhibition platforms (e.g., prime-time television, film festivals), and the themes and characters presented in her films are not binary opposites of hegemonic stereotypes. On the contrary, as with Toni Cade Bambara's corpus of work, Ayisi's films aim to expose the false binaries created by cultural and representational hegemony (i.e., rich/poor, developed/underdeveloped, free/oppressed) by depicting complex and multi-layered characters and issues and by deviating from typically reductionist mainstream or alternative stereotypes. As Billye R. Smith describes Bambara's themes, "these stories counter false dichotomies through featuring complex characters that fight against attempts to bisect their multi-faceted identities" (18-19).

In addition to depicting African topics, Ayisi's documentaries also focus on gender, constructing the woman as an individual and active member of a community. As an African woman, she attempts to take up the challenge presented by Nwachukwu F. Ukadike, in the context of redressing the way in which African women are portrayed, that "African women filmmakers are facing the challenge of regaining for women the power of self-definition and self-representation" (194). These films attempt to redress some elements of absence or misrepresentation of the lived experiences of African women. Accordingly, her work engages with alternative realities and visions that reveal positive lived experiences of African women and how these manifest in audio-visual representations. Thus, her narratives and characterizations ensure a wider audio-visual receptibility. Her agenda is influenced by the larger project of shifting the cinematic gaze and the "decolonization of culture." Through her films, she presents another way to look at Africa, which raises the following questions. Is there a paradigm shift through such constructions and perspectives? And if so, what kind of knowledge is borne out of these new ways of imagining different aspects of daily life in Africa from an African perspective? Also, how could these new images and this knowledge position the viewer to imagine cultural representations that offer viewpoints that move beyond the staple diet of negative stereotypes about African people and their societies? The two films discussed in this article address these questions through conscious choices in narrative and stylistic treatment.

Zanzibar Soccer Queens (ZSQ) is an upbeat and provocative portrait of a women's soccer team in Zanzibar, a predominantly Muslim society, that provides rare insight into African women's lives. The documentary presents personal stories of aspirations, shattered dreams, self-determination, friendship, and the confidence these women have gained from playing the sport. Despite opposition and limited facilities, the women succeed in playing the game they love, revealing that their determination to play soccer represents a larger desire for personal freedom and their passion for life. By persevering in their determination to play, the women's yearning to both better their lives and define new identities for themselves is revealed. Similarly, Art of This Place: Women Artists in Cameroon (WA) is an intimate documentary portrait of nine female Cameroonian artists. In the film, the women discuss and reflect on their work, showing the rich variety of their creative expressions in the visual arts, from wood sculptures to different forms of painting and ceramics. Through their artistic creativity, the women relate who they are as well 
as their particular visions for art, culture, and society. As one woman proudly says, "I bear witness to our life today, so that in 50 or 100 years, my art can express this period of time."

The core methodologies this article adopts for examining the two films are "representation" and "audience reception." Richard Dyer has argued that representation signifies how one group perceives members of another and that this perception informs the way in which the former treats the latter (White 1). In addition, Daniel Chandler states that representations that become familiar through constant reuse start to feel natural and unmediated and can even shape what we accept as the only reality (100-03). These formed stereotypes are not consciously perceived as such, nor is their simplicity or generalization questioned. Dyer and Chandler's theories emphasize the importance of representation not only as a phenomenon, but also as a methodology for scholarly research in production practices and audience hermeneutics. Thus, this article will examine how Ayisi's production choices have impacted on the viewer's interpretation of the story, the characters, and the space in the two films under consideration. The tandem of cognitive theory and phenomenology has been propagated by several scholars (e.g., Sweeney 37) to be an efficient hermeneutic framework that accounts for how a prototypical viewer would "read" the filmic text based on audio-visual and formal aesthetics. This constructivist perspective allows the bypassing of the cumbersome and conservative discourses of "realism" and "objectivity," focusing instead on Stella Bruzzi's notion of the "performative exchange between subject, filmmaker, and spectator" in relation to documentary production and consumption (6).

The following sections will analyze ZSQ and WA and show Ayisi's attention to a pan-African context (East and Central/West Africa), but also the diversity of socioreligious contexts, depicting low- and middle-class and Christian and Muslim women. In order to avoid the hierarchical dilemma in bottom-up and top-down approaches, the sections are based on thematic foci that are implicit in representation studies. The first section will look at "subjectivity and identity" and examine how the films aim to, firstly, establish individual female subjects and, secondly, make the audience identify with them. The second section will examine how that subjective storytelling is reinforced through "performance and agency," revealing how the director's production practices shift a substantial amount of authorship to the characters themselves. The third section will then discuss how "demystification" fosters character engagement among a multicultural mass audience by depicting topics, themes, and characters in a way that eliminates the stereotypical notions of "weirdness," "mystique," or "exoticism."

\section{SUBJECTIVITY AND IDENTITY}

Calling for a need to redress the way to "look" at and construct the African subject in (Western) media texts, Malian filmmaker Souleymane Cissé laments the way in which Europeans filmed African subjects: "They came to show us to their audiences as though we were animals. ... White camera shows Africans as not belonging to the human community. They film wild animals with more respect" (qtd. in Barlet 5). Cissé proposes that the duty of African filmmakers is "to affirm that people here are human beings and to make known . . . our values which could be of use to others" (Ibid. 13). Thus, in order to fully break with imperialistic 
practices, Cissé urges a fundamental shift in representing the characters who were once subjugated by colonial powers and then constructed and portrayed through, what Barlet calls, the "ethnological gaze" (6-9). This shift turns the object into the subject, who is preoccupied with important values that "others" could find useful. Referring to the "audience-text" relationship, Cissé implicitly proposes the establishment of subjectivity and identification within the text.

Murray Smith's cognitive identification model offers a reasonable approach for examining how films use narrative and aesthetic cues to construct character identification, thus making the spectator empathize with the screen subjects (34-35). Even though Smith's model is most often applied to fiction films, it can equally be applied to nonfiction films, whether their narratives depict hermetic diegeses (such as observational documentaries), authorial commentaries (such as expository and poetic documentaries), or reflexive discourses (such as performative documentaries). Smith distinguishes between three levels of gradual identification by audiences: recognition, alignment, and allegiance (39).

Recognition involves the continuous visual perception of the human body, especially those body parts that evolution conditioned us to use for individual identification, such as the face, hair, and hands. In this respect, recognition can be extended to the visual emphasis of costume and body artifacts, which are quasiextensions of one's body. ZSQ and WA make constant use of close-ups of faces, hands, skin, and clothes. Furthermore, the choice to let the women in ZSQ speak in Swahili, their own language, and using subtitles instead of a dubbed voice-over, also allows the audience to aurally recognize these characters. Ngũgĩ wa Thiong'o remarks that, within the larger project of decolonizing African culture, "it is on the screen where we encounter African people speaking their own languages.... African cinema has taken a giant stride in rejecting the neo-colonial notion that ... African people can express themselves only in foreign languages" (95-96). Apart from the use of their native tongue, the film editing highlights the soccer players' linguistic and emotional identity by keeping the verbal pauses, hesitations, or repetitions instead of omitting them. Nevertheless, Smith points out that this first stage of recognizing a character does not yet involve empathy or identification. It is, rather, an automatic phenomenological experience that renders the viewer receptive to the next two stages.

The second stage, alignment, constitutes the viewer's access to the screen character. Here, Smith distinguishes between "spatial attachment," the physical space around characters and the audience's perception of it, and "subjective access," or access to the character's psychological state (41). Maurice Merleau-Ponty deconstructs space into the dialectical relationship between "bodily space," the somatic experience of the subject evoked by a specific physical space, and "objective space," the primordial understanding of that space to achieve a sense of orientation, both of which are essential for human perception (115-16). In Ayisi's films, this spatial experience of screen characters is transposed onto the viewing experience of the audience. To achieve this, she makes frequent use of extreme wide shots and close-ups. In a conventional continuity style tradition, the wide shots establish an important "supporting point" for the viewer's geographical understanding of the objective space (Merleau-Ponty 156). However, she complements this by constantly using the visual motifs of surfaces and texture (as in WA) through close-ups, thus recreating the "bodily space" of the characters. Laura 
Marks refers to this as the "haptically charged surface[,] such as the close-up of ... any conspicuous and interesting texture" (qtd. in Elsaesser and Hagener 114). Thus, the eyes function as organs of touch, letting, what she calls, "haptic images" appeal to a more complex multisensory perception. It is exactly this conditioned viewing experience of subjective micro-context and objective macro-context that makes the audience not only "recognize," but also "feel" characters and their spatial surroundings.

Within Smith's alignment stage, subjective access allows the audience into the character's psychological state. $Z S Q$, in particular, employs impressionistic shooting and editing techniques (e.g., slow-motion) to reflect the emotional states of subjects at a particular time in the narrative, thus, motivated by the plot, not by authorial decisions. For example, when one soccer player proudly recounts her first game, the scene cuts to a flashback of her in that game in slow-motion, the slow-motion representing the lingering and pleasant memory. Another technique for creating "subjective access" is depicting and juxtaposing different identities for the same individual, thus subverting the idea of the "monochromatic character of the French and British anthropological traditions" (Jules-Rosette 951). For instance, in $Z S Q$, the dual identities of these Muslim women are visually encoded by dress, both as transgressive soccer players, wearing shorts and T-shirts when on the field, and as conformists to religious and traditional boundaries, as they wear Khangas in their everyday lives.

This distinction is highlighted by juxtaposing two scenes of the same character, Warda. In one scene, she prepares for prayer by washing her hands and feet, then wraps the Khanga around her body before she begins to pray in silence. In another, Warda washes the team's soccer jerseys. Both scenes take place in the same location, her home; use the metaphor of water, signifying the (re)birth of a new identity; and use close-ups to emphasize the importance of the two styles of dress. Through these similarities, the audience can cross-reference these two events. However, both scenes also use binary differences, such as silence (praying) versus washing sounds and voice-over, thus aesthetically emphasizing and comparing the two identities. Coupled with Warda's significantly different body language and facial expression in both scenes, the audience gets direct access to two "subjectivities." In addition, there are also several scenes in the film where the female players unveil their bodies to reveal their soccer gear underneath, in full view of the public, which, through reaction shots and cutaways, is often seen to be male. They, thus, metaphorically reveal their inner selves beneath traditional restrictions. This dichotomy of transgression vs. conformity in these women's identities is synecdochal for all women in Ayisi's films.

Smith's last stage of audience identification, allegiance, refers to the moral and ideological evaluation of the character on screen. The themes of the documentaries, which are always expressed by the subjects, reflect ideological and moral values that resonate beyond their sociocultural and geographical contexts. Typical themes in ZSQ and WA are the search for and expression of identity, freedom, and social acceptance. The women in these two films express a strong sense of collective dynamism, survival strategies, and their desire to assume other identities outside their traditionally defined roles as wife, mother, cook, and caregiver. These global themes place African women in a macrocosmic discourse and make an international audience identify with them. After all, the 
desire to have choice and freedom of self-expression and to define one's self is a universal and human condition that cuts across cultural and gender lines. Even the occupations of the subjects and the inherent ideological implications reveal a break with stereotypical representations and relate to a universal context: the professions and activities of soccer players and artists are shared by people and communities around the world.

Murray Smith's character empathy model primarily accounts for how cinematography, editing, and narrative structure are used to reveal human features and traits. However, both documentaries also make conceptual use of "space" by utilizing wide shots coupled with a wide-angle lens. This treatment creates a deep focal range in which the space metaphorically describes the women. ${ }^{2}$ For example, when Zuwena, the goalkeeper in $Z S Q$, is interviewed, the long, visible coastline in the background represents the long and obstacle-ridden path her life has taken, as well as her current liminal stage from a nomadic to a settled life. In the training sequences, the soccer field defines a space where the women experience the freedom to express their ideas and dreams through their bodies. Additionally, the frequent presence of palm trees in the background serve as visual motifs: their ability to bend in the wind but not break is a metaphor for the women's struggle against the traditional opposition to play soccer. Thus, the space becomes not only iconic for the island of Zanzibar, but also defines its inhabitants. There is a strong connection between characters and their spaces, expressing a sense of community and belonging that is deeply rooted in how they perceive and relate to the environment.

Furthermore, the symbolic use of objects is prominent in both films. In $W A$, the women's varied artwork boldly represents them as young, contemporary fine artists whose form and style are inspired by their cultural and traditional values. $Z S Q$, on the other hand, uses the soccer ball and the women touching it in different ways as a recurrent motif: the very opening shot shows a ball being kicked with stylized sound. Other shots show the women tapping the ball, rolling it on different parts of their bodies, and performing headshots. Through cinematography and editing this motif of touching the ball (which is a skin in itself) evokes, once more, Laura Mark's "haptic vision" in the audience and reflects what playing soccer means to the women, an objectified characterization reminiscent of the radios in Ousmane Sembene's Moolaadé (2004) and the bicycle in Marzieh Makhmalbaf's The Day I Became a Woman (2000).

Ayisi's strategy of using these motifs as metaphors and, at the same time, understating their iconic meaning, by showing them as natural elements of the mise-en-scène, reduces the artificiality of deliberate authorship. The omission of self-referential symbolism creates a coherent diegesis in which the spectator can be immersed without authorial barriers. In addition, by eschewing over-stylization and using a subjective point of view, the films' narrative structures and aesthetics pursue an epistemology that strictly relates to the subjects' experiences and emotional states. There is hardly any instance of deliberately concealed information to create the effect of "suspense" or "surprise." The exposition of information (which is mostly of a subjective, not thematic, nature) occurs organically and naturally in the process of self-revelation. Thus, the authorial point of view is reduced to a minimum in order to prevent a sense of Brechtian defamiliarization on the part of the audience. Striving to remove the director as a narrative catalyst is palpable 
in interviews where the eye line of the interviewee is very close to the camera. The shots of women looking straight into the camera toward the end of WA, for example, connect directly with the viewer because they virtually bypass the filmmaker. Consequently, the characters are becoming authors in their own right.

\section{PERFORMANCE AND AGENCY}

In Transcultural Cinema, David MacDougal asks the question, "Whose story is it?," initiating a critical discourse that deals with the ontology and ethics of authorship in ethnographic films (150). He points out that the tendency toward "dialogic and polyphonic construction in ethnography" (Ibid.) has resulted in an emphatic shift from the author's voice to that of the depicted subject, but that this new paradigm is not without problems, for the question remains as to whether a documentary is dispersing some of its authority on its subjects in order to grant them a shared authorship or to reinforce its own (he uses the interview as an example of this dilemma). MacDougal's overall position suggests that using "indigenous" storytelling techniques purely as a stylistic or ideological device reinforce the authorial voice. Consequently, a more genuine form of shared authorship is achievable if the narrative point of view, as a whole, is subjective (as discussed previously) and a different, more open, and less structuralist attitude is embraced by the filmmaker during the entire production process.

Ayisi's approach to filmmaking seeks to provide a higher degree of visibility in terms of image and voice and a context in which the audience can perceive the subjects on screen and gain a deeper awareness and understanding of them through direct engagement. ZSQ and WA not only offer visible evidence of African women, but also give these women the opportunity to establish their own identities through performance. For Catherine Summerhayes, documentary participants can also be seen as performers. Specifically referring to observational cinema, she states, "these people [whose performances are filmed in nonfiction film] frequently have more control over the profilmic events . . than the producer, director, and camera-operator" (78). This shared authorship is also shaped by the agenda and approach of the filmmaker. Kate Nash similarly observes that, at least to some degree, participants in documentaries are requested to perform within the context of the filmmaking and the filmmaker's agenda (95). Thus, they may become aware of this and implicitly or explicitly negotiate with the filmmaker about what kind of performance is suitable. As a result, the performance of the participant becomes a collaboration, a construction by the participant and the filmmaker (Nash 95). Ayisi's work encourages this symbiotic relationship between author and subject by giving a considerable amount of agency to the characters.

Although Nash and Summerhayes refer to observational documentaries and actuality scenes, which frequently feature in Ayisi's films (e.g., women playing soccer, painting, praying, performing household chores, etc.), this negotiated agency of profilmic events is also possible in interviews. Negotiated agency is represented in Ayisi's films in the following ways: the women in both films were asked to choose the locations for their interviews beforehand, the women featured in ZSQ selected the soundtrack for the film, and Ayisi not only showed the women in ZSQ a teaser for the film before filming was completed, but took their comments into consideration. The most iconic example of this negotiated agency is Zuwena, who 
chose to be interviewed in her goalkeeper uniform on the beach. Ayisi seeks in all her interview sequences to avoid interference from preconceived ideological or narrative agendas with the topics discussed by using open-ended questions. In addition to targeted questions, the women in the film were also given the freedom to talk about whatever they wanted, resulting in insightful anecdotal accounts. Negotiated agency is also reflected in ZSQ because the women were asked to choose the soundtrack for the finished documentary. The choice of Taarab songs (a very popular style in Tanzania and Kenya) featuring strong female voices and lyrics that reflect the subjects' own lives and dreams creates local color that is often missing in transnational documentaries. In addition, between the first and second filming stage in Zanzibar, the director showed the main characters a short workin-progress version of the documentary (a 12-minute teaser), which prompted reactions and feedback that were considered in the production stage. Thus, African women's lives and experiences are represented through the women's own words, narrating and creating their own herstories. They are creating a space (physical and emotional) from which to speak for themselves that produces a politicization of identity in the context of Ayisi's wider agenda of representation that fulfills the larger project of "decolonization of culture." It also decolonizes the cinematic gaze, as discussed by Barlet (6-9), and is exemplified in the films of many African filmmakers, such as Safi Faye, Ousmane Sembene, Soulemane Cissé, Gaston Gabore, Haile Gerima, and Anne-Laure Folly.

However, the performance of the women does not only contribute to a shared authorship, it also brings forth another dimension of themselves. According to Erving Goffman,

\begin{abstract}
... when one's activity occurs in the presence of other persons, some aspects of the activity are expressively accentuated, and other aspects, which might discredit the fostered impression, are suppressed. It is clear that the accentuated facts make their appearance in what I have called a front region; it should be just as clear that there may be another region—a "back region" or "back-stage" where the suppressed facts make an appearance. (114)
\end{abstract}

In the context of documentary filmmaking, this means that the presence of the camera provides an even higher level of "expressively accentuating" some aspects of oneself, those that are the focus of the proposed film. Erik Barnouw, for example, comments on the filmmaking approach of Jean Rouch, the French filmmaker and anthropologist. As explained by Barnouw, Rouch's idea of a camera as a "catalytic agent" means that another facet of a subject's identity is revealed in the cinematic process, thereby projecting a hidden truth that cannot be obtained by any other means. Barnouw notes that Rouch believed "the presence of the camera made people act in ways truer to their nature than might otherwise be the case" (253). The manner in which the women tell their individual stories in ZSQ and WA arguably reveals their performance as being "truer to their nature." The camera is not only a catalyst but also a democratic apparatus for the women, enabling them to transcend their traditional societal roles as housewives and child bearers and providing them with the opportunity to re-present what has hitherto remained invisible. Their stories and images re-present perspectives that move beyond the familiar mainstream images of misery and despair. 
The notion of agency is also visible in the representation of the women's memories. Memory, according to Teshome Gabriel, “does something else besides telling us how we got here from there: it reminds us of the causes of difference between popular memory and official versions of history." This official history "privileges the written word of the text ... it claims a 'centre' which continuously marginalizes others" (53). Thus, the scenes in which the women remember and recount is a form of oral history, especially when one considers that most ordinary African women are semi-literate, do not have access to any form of media (neither written nor electronic), and are discouraged from expressing themselves in their respective societies. Because of this, they have to use indirect ways of expressing their needs and dreams, such as the arts and sports. Consequently, remembering and recounting is a form of resistance, resisting the possibility of being forgotten, and provides validation for experiences that are important in the context of a collective consciousness. For example, the soccer coach in ZSQ, Nassra, recollects the history of her team (Women Fighters' FC), how they formed to play against a visiting Swedish female team, how the novelty of a local soccer team was received in the patriarchal society, and how they got to lead the Women's League and became the "Queens of Soccer in Zanzibar." These memories are not only personal, but establish a public collective memory since they represent the history of female soccer in Zanzibar. They bring the unheard, lost, and forgotten world of women's experiences in sports back to the fore. They revitalize and redefine what this small group of women are doing and what happened many years ago. Nassra's memory renders the facts and an important part of women's unknown history of soccer in Zanzibar visible. As Paula Rabinowitz says about photographing "ordinary people," this process produces a new awareness, as the images of daily life are brought "into public view, photography remakes vision and ... produces (or reproduces) new forms of (class) consciousness" (35). Such awareness could work toward empowering people who were once silent, absent, or invisible.

The interview scenes in ZSQ are substantiated through a variety of archive photos and news articles. However, apart from a few exceptions, all archive materials come from the personal belongings of the women, especially the older founding members of the team, Nassra and Amina, because official records in local newspapers or from television do not exist. Thus, the collective and individual history of these women is embedded in this kind of "unofficial" memory that is securely anchored in the practice of their material lived experiences, which they retell with passion and nostalgia. This nostalgia could also be understood in this context as a form of resistance. Nassra remembering the official birth of women's soccer in Zanzibar produces a new history, or a herstory of sorts, one that provides a platform for a shared consciousness of what playing soccer means beyond the borders of their country and culture.

The idea of ordinary women telling their stories with their own agendas and from their perspectives is essential within the broader context of how women articulate and redefine their identities and roles in modern African societies. Women's determination to play soccer and to create works of art is symbolic and visionary in the wider framework of development challenges and the aspirations of the African woman. Ayisi's films adapt this real-life empowerment into filmic form by empowering the women's screen personas through subjective point of views, constructing visible identities, and sharing authorship with them. Thus, the 
spectator not only intellectually learns about an empowered African womanhood, but also feels it as an active perceiver of the documentary stories. The agency of the women in real life is experienced through narrative, aesthetic, and performative agency on-screen.

\section{DEMYSTIFICATION}

In The Invention of Africa (1988), philosopher Valentin Y. Mudimbe discusses Western anthropological traditions as part of an epistemological orientation that positions African subjects as voiceless "others" (qtd. in Jules-Rosette 952). Mudimbe, who borrows the term "other" from Edward Said's Orientalism, states that three types of representation have contributed to the invention of primitive Africa: exoticizing, taxonomizing, and primitivizing (Ibid. 952). These three complementary approaches contribute to a mystification of the colonially perceived subculture, thus producing the perception of the "other." Referring to film and the apparatus, the notion of the "other" is conventionally reinforced by distancing the viewer from the pro-filmic event and the characters. This can either occur through Brechtian defamiliarization or the lack of subjective point of view, both of which were addressed earlier. Ayisi's documentaries aim to demystify and de-exoticize African subjects through narrative structure and themes.

Darcy Lynne Ark examines how Andre Dubus III's novel House of Sand and Fog uses narrative strategies to undo the exoticism of the "other" (26). Dubus III uses simple, yet effective analogies and links to highlight the similarities between two cultures (American and Persian), most prominently depicting the subjectivized story of an Iranian immigrant family with emphasis on mundane, everyday life events and routines (37-39). This strategy of demystification recurs in ZSQ and $W A$ where the women are seen performing ordinary routine activities through observational aesthetics. In combination with the aforementioned strong personal voice, this technique places the viewer as an active observer in the pro-filmic events and spaces that present an active subject. In $Z S Q$, this concrete sense of space and time is reinforced by emphasizing the passage of time through sunset/ sunrise shots and night/morning shots as diegetic visual cues, a strategy extensively used in Être et Avoir (Nicolas Philibert, 2004). Larger time compressions are smoothed with text or montage sequences that fill the diegetic gaps. This phenomenological sense of diegetic time and the women's everyday space aids the viewer in cognitively mapping temporal periods, the topography of the space, and the sociocultural performance of the character. This tangibility aims to prevent any kind of abstraction and mystification.

Elaborating more on the representation of space, it is often apparent that films have an affinity for portraying non-Western (or "other") actions or events by predominantly using close-ups, justifying this practice as an almost ethnographic exploration of culture through detail and texture. Alas, the obsession of some filmmakers with close-ups creates a spatial abstraction that conceals not only the physical space, but also body language and character positions in relation to each other. This tends to render mundane actuality events into romanticized or mystified rituals. In a Bazinian tradition, other documentary filmmakers predominantly use wide shots to focus on body language, thus examining proxemic behavior, but compromising the palpability of facial expressions and texture. Ayisi's films use 
both approaches in conjunction with one another and, through these, provide a sense of "bodily space" and "objective space" (Merleau-Ponty 115-16), as discussed earlier.

The visual treatment of space and time through continuity of style, which enables cognitive orientation for the viewer, is deeply anchored in the Western perception of fiction films and observational documentaries. It addition, it shows once more why Ayisi's documentaries are aimed at a mainstream audience. She refuses to use purely alternative audio-visual forms that would render her work suitable only for a niche audience-as is the case with most experimental and ethnographic films - preferring, instead, conventions that a mass audience can easily decode. Therefore, her films, which are not anthropological but have ethnographic aspects, attempt to solve the dilemma that MacDougal describes in relation to anthropological filmmakers:

Anthropology, in its traversing of cultural realities, is always on the verge of the surreal, but it endeavours to neutralise what Malinowski called the "coefficient of weirdness" through the rationale of cultural translation. The lesson of surrealism, however, is that the experience of paradox is in itself significant and must be grasped to generate new perceptions. (150)

MacDougal's statement indicates that ethnographic filmmakers still tend to portray the "other" and that the "exotic" should be embraced and represented as such. He seems to dismiss the possibility of deconstructing seemingly "surreal" or "paradox" traditions into transcultural human themes and traits. Ayisi's documentaries consciously deal with global and fundamental issues of the "self," instead of being concerned with how to represent the potential paradox of different cultures. Every character is given the voice to define and redefine their identity and to reveal different identities, whether personal or collective, realistic or idealized, in private or public spaces. Consequently, her films achieve the "cultural translation" MacDougal mentions by exposing significant similarities between African people and Western audiences. However, whereas Andre Dubus III creates this comparison within the text of House of Sand and Fog (both juxtaposed cultures are part of the diegesis), Ayisi goes one step further by transposing the African point of reference onto the Western viewer, bypassing the need for an on-screen persona representing them. Firstly, this allows her films to fully focus on African subjects without clumsily juxtaposing the "white" and the "black" in a pseudoliberal attempt to decolonize the gaze. Secondly, it enables a Western audience to identify (rather than compare themselves) with the depicted characters and, thus, discover transcultural and transgender similarities that are neither paradox, nor exotic, nor surreal.

Apart from the human themes in Ayisi's films, it is also worth mentioning her interest in certain occupational contexts, namely soccer, art, and the legal system (in Sisters in Law). The benefits of these thematic interests are evident: their universality reinforces global human interest themes and stories and it also breaks down gender stereotypes. The human need to make art and to play soccer does not exclude African women who are determined to be creative and express themselves. Thus, African women are not seen as the "other," or the "oppressed," in her films. Their identity shifts from the limited stereotypical ways in which women 
are generally defined, framed, and constructed to ideas and images that reveal another level and depth of their own sense of who they are within the tangible specificities of their surroundings.

\section{CONCLUSION}

The fabric of African women's lived experiences and memories is woven in specific images and spaces over time. The choice of using documentary film as a site for not only asserting African women's experiences and identities, but also establishing and preserving their images is significant in the discourse of (in)visibility. The women's personal stories, their passion for arts and soccer provide privileged insights into the aspirations and hidden worlds of women whose access to, and presence in, the media is usually limited or absent. It is through their visually encoded multiple dimensions that their shifting status and actual lived experiences are validated. Their universally shared experience of soccer and engagement with the arts connects them to countless imagined communities of other women with similar experiences and ambitions. Thus, they too become part of history and a mainstream consciousness that speaks about cultural representations of women in a globalized context of digital mass media. In this way, audienceswhether in the national or transnational context-gain a different understanding of the African women's empowered womanhood. We hope the discussions and analyses have attempted to address, what Ukadike calls, "a revisionist dialogue" (194-95), both in terms of the acts and politics of representing aspects of African culture and also the visible evidence of women's increasingly changing positions in modern African societies.

We have argued that the project of making the affirmative aspects of African culture visible has to also take account of a wider circulation of these images. This underpins what Imruh Bakari refers to when he says, "Africa has to free itself from the ... bondage of the Western regime of memory, consciousness, and order within which Africa's subjectivity as a modern construct is enmeshed" (11). ZSQ and WA have been screened on television and at film festivals around the world. ${ }^{3}$ These screenings play an important sociocultural role in mainstreaming other images of African women. In the case of $Z S Q$, the production process and screenings expanded the women's visibility beyond their country, connecting them with communities, individuals, and organizations outside their sociocultural spaces. ${ }^{4}$ The films and the screenings provide a platform for audiences to engage with and imagine the changing landscapes of African cultures in complex socioeconomic, postcolonial, and global contexts and, through these, present another way of seeing. As Ngũgĩ wa Thiong'o declares, "no living culture is ever static" (qtd. in Ukadike 21).

Film production and audience reception are inextricably linked in the process of determining ideas around the (in)visibility of cultural representations. In the context of African cultures, the implications for audience reception and perception are crucial for evaluating the "new" consciousness produced by decolonized cinematic gazes and images through African lenses "looking" at themselves. Could such representations work toward transforming ways of seeing and perceiving African people? Where and how do these images reach a wider audience? These and other questions about how the new visions of Africa impact the viewing 
public deserve further research. In relation to a wider circulation of alternative African images, Kenneth W. Harrow has noted that "the work of women filmmakers is relatively unknown, except for local audiences and specialists ... there is little recognition for ... what continues to become a growing, important body of womanist, feminist, or simply female cinema" (vii). What if a majority of these images only exist in limited exhibition circuits? Without an empirical audience reception study to analyze how the films are received and interpreted, one can only speculate about the implications of the increased visibility of images that speak differently about African people and their cultures. Interpretations of films (both fiction and documentary) by audiences in Africa and the West have to be concretely established to determine the ideological impact of the changing nature and visibility of African cultures. Also, more work is required to explore and analyze the contributions by African filmmakers on the continent and in the diaspora to redefine our understanding of African life, identities, and societies in terms of alternative cultural representations. Florence Ayisi's work in disseminating information, ideas, and stories through the two documentary films discussed in this article continues in other media. ${ }^{5}$

\section{NOTES}

1. Examples of filmmakers whose body of work has, over the years, provided a revision of African identities, histories, and cultures from Afrocentric perspectives include Ousmane Sembene (Ceddo, 1977; Xala, 1975; Moolaadé, 2004), Gaston Kaboré (Buud Yam, 1997), Idrissa Ouedraogo (Yaaba, 1989), Safi Faye (Kaddu Beykat, 1975; Mossane, 1996), Med Hondo (Soleil O, 1970; Sarraounia, 1986), Soulemane Cissé (Yeleen, 1987; Waati, 1995), Haile Gerima (Sankofa, 1993), Gaston Gabore (Wend Kuuni, 1982; Buud Yam, 1997), Mahamat Saleh Haroun (Abouna, 2002; Darrat, 2006), Idrissa Ouedraogo (Samba Traore, 1972; Tilai, 1990), Abderrahmane Sissako (Waiting for Happiness, 2002; Bamako, 2008), Djibril Diop Mambety (Touki Bouki, 1973; Hyènes, 1992), Désiré Ecaré (Visages de femmes, 1985), and Jean-Pierre Bekolo (Quartier Mozart, 1992).

2. This is also seen in films like Ousmane Sembene's Moolaadé (2004), Safi Faye's Lettre Paysanne (1975), and Idrissa Ouedraogo's Tilai (1990).

3. Screenings of ZSQ at festivals in New York, Zurich, and Germany and on television stations including SVT (Sweden), Qatar TV, EITB (Basque region in Spain), The Community Channel (UK), TV5 Monde Afrique, and RFO TV (France) generated a lot of public interest in and support for the women. For more information on the screenings, see "Art of This Place: Women Artists in Cameroon-Festival Screenings and News" and "Zanzibar Soccer Queens-Festival Screenings and News."

4. The team was invited to visit Germany in September 2009 after ZSQ was screened at the Globians Film Festival in Potsdam. The process of making ZSQ helped establish links between the team and Mama Cash International (Netherlands). The coach received a small grant to support her work and sustain the team. Soon after ZSQ was screened at the Pink Apple Film Festival in Zurich in 2009, the team received material support from FIFA.

5. Over 90 hours of footage was shot for $Z S Q$, even though the finished film exists in 87 and 52 minutes versions. Over 10 hours of rushes were shot for WA. As part of continuing the process of disseminating the women's varied stories and images, the authors are developing a major Internet project using the format of a database narrative. They are also planning to conduct an audience reception study for both films through focus group research in a European and an African context. 


\section{WORKS CITED}

Achebe, Chinua. "An Image of Africa: Racism in Conrad's 'Heart of Darkness.'” Massachusetts Review 18.4 (1977): 782-94. Print.

Ark, Darcy Lynne. "Demystifying House of Sand and Fog through Postcolonial and Feminist Lenses." MA thesis. Bowling Green State University, 2007. Print.

"Art of This Place: Women Artists in Cameroon-Festival Screenings and News." Iris Films UK. Florence Ayisi, n.d. Web. 6 Feb. 2013.

Bakari, Imruh. "Introduction: African Cinema and the Emergent Africa." Symbolic Narratives/African Cinema: Audiences, Theory, and the Moving Image. Ed. June Givanni. London: British Film Institute, 2000. 3-24. Print.

Barlet, Olivier. African Cinemas: Decolonizing the Gaze. London: Zed Books, 2000. Print.

Barnouw, Erik. Documentary: A History of the Non-Fiction Film. Oxford: Oxford UP, 1993. Print.

Bruzzi, Stella. New Documentary: A Critical Introduction. New York: Routledge, 2000. Print.

Cham, Mbye. Introduction. African Experiences of Cinema. Eds. Imruh Bakari and Mbye Cham. London: British Film Institute, 1996. 1-16. Print.

Chandler, Daniel. The Basics: Semiotics. New York: Routledge, 2002. Print.

Cohn, Theodore H. Global Political Economy: Theory and Practice. New York: Longman, 2004. Print.

Diawara, Manthia. African Cinema: Politics and Culture. Bloomington: Indiana UP, 1992. Print.

Dyer, Richard. The Matter of Images: Essays on Representation. London: Routledge, 1993. Print.

. White. London: Routledge, 1997. Print.

Elsaesser, Thomas, and Malte Hagener. Film Theory: An Introduction through the Senses. Oxon: Routledge, 2010. Print.

Gabriel, Teshome. "Third Cinema as Guardian of Popular Memory." Questions of Third Cinema. Eds. Jim Pines and Paul Willemen. London: British Film Institute, 1989. 53-64. Print.

Goffman, Erving. The Representation of Self in Everyday Life. London: Penguin, 1959. Print.

Groshek, Jacob, and Ying Han. "Negotiated Hegemony and Reconstructed Boundaries." Alternative Media Coverage of Globalization. International Journal of Communication 5 (2011): 1523-44. Print.

Harrow, Kenneth W. Introduction. With Open Eyes: Women and African Cinema. Ed. Kenneth W. Harrow. Amsterdam: Rodopi, 1997. vii-xii. Print.

Jules-Rosette, Benetta. "Speaking About Hidden Times: The Anthropology of V. Y. Mudimbe." Callaloo 14.4 (1991): 944-60. Print.

MacDougal, David. Transcultural Cinema. Princeton: Princeton UP, 1998. Print.

Merleau-Ponty, Maurice. Phenomenology of Perception. 1945. New York: Routledge, 2002. Print.

Nash, Kate. "Beyond the Frame: A Study in Observational Documentary Ethics." Diss. University of New England, 2009. Print.

Ngũgĩ wa Thiong'o. "The Homecoming of African Cinema." Symbolic Narratives/African Cinema: Audiences, Theory, and the Moving Image. Ed. June Givanni. London: British Film Institute, 2000. 239-41. Print. 
Petty, Sheila. "Black African Feminist Film-making?." African Experiences of Cinema. Eds. Imruh Bakari and Mbye Cham. London: British Film Institute, 1996. 185-93. Print.

Pratt, Nicola. "Bringing Politics Back in: Examining the Link between Globalization and Democratization." Review of International Political Economy 11 (2004): 311-36. Print.

Rabinowitz, Paula. They Must Be Represented: The Politics of Documentary. London: Verso, 1994. Print.

Smith, Billye R. "Countering Hegemony through Synthesis: A Lifetime of Commitment to the Black Community in the Works of Toni Cade Bambara." MPS thesis. Cornell University, 2006. Print.

Smith, Murray. "Character and Emotional Response in the Cinema." Cinema Journal 33 (1994): 34-56. Print.

Solanas, Fernando, and Octavio Getino. "Towards a Third Cinema." Documentary Is Never Neutral. Documentary Is Never Neutral, n.d. Web. 20 Sept. 2011.

Summerhayes, Catherine. "Film as Cultural Performance." Diss. The Australian National University, 2001. Print.

Sweeney, Kevin W. "The Persistence of Vision: The Re-Emergence of Phenomenological Theories of Film." Film and Philosophy 1 (1994): 29-37. Print.

Ukadike, F. Nwachukwu. "Reclaiming Images of Women in Films from Africa and the Black Diaspora." African Experiences of Cinema. Eds. Imruh Bakari and Mbye Cham. London: British Film Institute, 1996. 194-208. Print.

Wynter, Sylvia. "Africa, the West, and the Analogy of Culture: The Cinematic Text After Man." Symbolic Narratives/African Cinema: Audiences, Theory, and the Moving Image. Ed. June Givanni. London: British Film Institute, 2000. 25-76. Print.

"Zanzibar Soccer Queens-Festival Screenings and News." Iris Films UK. Florence Ayisi, n.d. Web. 6 Feb. 2013. 